\title{
Behavior of laying chicks fed diets containing sources and levels of dietary fiber in the starter phase
}

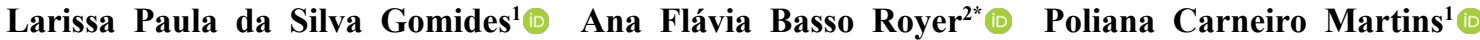 \\ Genilson Bezerra de Carvalho ${ }^{1}\left[\right.$ Pedro Moraes Rezende ${ }^{1}$ (๑) Marcos Barcellos Café ${ }^{1}[$ \\ José Henrique Stringhini ${ }^{1}$ (D)
}

${ }^{1}$ Universidade Federal de Goiás (UFG), Escola de Veterinária e Zootecnia (EVZ). Goiânia, GO, Brasil.

${ }^{2}$ Instituto Federal do Mato Grosso do Sul (IFMS), 79750-000, Nova Andradina, MS, Brasil. E-mail: ana.royer@ifs.edu.br. "Corresponding author.

ABSTRACT: This study evaluated the behavior and welfare conditions of laying chicks in the starter phase, fed with diets formulated with increasing levels of crude fiber $(C F)$ and two feedstuffs with different fiber compositions. The experiment was developed at the Federal University of Goiás, in Goiânia - GO, Brazil. Three hundred Bovans White chicks were evaluated in a completely randomized design with a $2 \times 2+1$ factorial arrangement corresponding to two levels of $C F$ in the diet (3.0 and 3.5\%) and two fiber sources (wheat bran and sugarcane bagasse), plus a control treatment (maize- and soybean meal-based), totaling five treatments with six replicates of 10 birds each. Maintenance behavioral patterns and welfare were assessed at 21 and 42 days of age. There was no difference in behavior and classification by order of importance of the activities performed by the fiber-fed birds observed at 21 and 42 days, according to the Kruskal Wallis test (P>0.05). Medium and good welfare conditions were obtained with wheat bran at 3.5 and $3.0 \%$ CF, respectively, at 21 days of age. At 42 days, the use of sugarcane bagasse at the CF level of $3.5 \%$ and wheat bran at the level of $3.0 \%$ provided good behavior conditions. The use of crude fiber in the feeding of hens did not change their behavior.

Key words: behavior, sugarcane bagasse, wheat bran.

Comportamento de pintainhas de postura leve alimentadas com dietas contendo fontes e níveis de fibra dietética na fase de cria

RESUMO: Objetivou-se avaliar o comportamento de pintainhas de postura na fase de cria, alimentadas com dietas formuladas com aumento de fibra bruta e dois alimentos com composições de fibra diferentes. O trabalho foi realizado na Universidade Federal de Goiás, Goiânia, GO, utilizando-se 300 pintainhas Bovans White, em delineamento inteiramente casualizado e arranjo fatorial $2 x 2+1$, com dois niveis de fibra bruta na dieta (3,0\% e 3,5\% de FB), duas fontes de fibra (farelo de trigo e bagaço de cana) e o tratamento testemunha (ração a base de milho e farelo de soja), totalizando cinco tratamentos e seis repetições de 10 aves cada. Foram avaliados padrões de comportamento de manutenção e bem-estar aos 21 e 42 dias de idade. Não houve diferença no comportamento e na classificação por ordem de importância das atividades realizadas pelas aves alimentadas com fibra e observadas aos 21 e 42 dias pelo teste de Kruskal Wallis (P>0,05). Obteve-se condições média e boa com farelo de trigo e 3,5 e 3,0\% de fibra bruta, respectivamente, com 21 dias de idade. Aos 42 dias, o uso de bagaço de cana ao nível de 3,5\% de fibra bruta e o farelo de trigo ao nível de 3,0\%, mostraram boas condições de comportamento. A utilização de fibra bruta na alimentação de frangas não alterou o comportamento das aves.

Palavras-chave: bagaço de cana, comportamento, farelo de trigo.

\section{INTRODUCTION}

The concern with animal welfare has culminated in changes in cage-based (battery) poultry farming systems. In this respect, identifying behavioral repertoires responsive to the rearing environment can validate welfare conditions (BATISTIOLI et al., 2016). By monitoring the behaviors expressed by the animal, it is possible to better assess its quality of life and production performance (GARCIA et al., 2015).
Natural behaviors of the species, such as running and scratching, have a positive implication for laying poultry. Chickens reared on bedding material, for example, have their wallowing and scratching behaviors stimulated (MOURA et al., 2017). However, in cage and/or high-density farming, scratching is naturally replaced by the act of biting the cage grids or feather-pecking, which vary in intensity between genetic lines and ages and are an indication of increased stress (PEREIRA et al., 2015). Under 
this situation, chickens may also display aggressive behaviors, including other stereotypies. Additionally, when reared in environments with limited space, they may tend to reduce their activities and remain idle or lying down for long periods (GARCIA et al., 2015).

However, laying hens raised in cages and fed with feedstuffs with insoluble and soluble fiber composition have shown controlled feather pecking and cannibalism in response to the increased gastrointestinal passage rate (GUZMÁN et al., 2015). It is believed that feedstuffs with a higher amount of insoluble fiber fractions are retained in the gizzard for grinding and soluble feedstuffs can increase the viscosity of intestinal mucosa due to the solvation capacity of some constituent sugars. In this way, the availability of nutrients for the bird is reduced, thereby extending feed intake time. As a result, idle time and the act of biting combs and feathers of neighboring birds are reduced (MANCABELLI et al., 2016).

In this scenario, this study aimed to assess the behavior and welfare characteristics of chicks in the starter phase $\left(1^{\text {st }}\right.$ to $6^{\text {th }}$ weeks of age) using diets with increasing levels of crude fiber obtained through the inclusion of sugarcane bagasse and wheat bran in the formulation.

\section{MATERIALS AND METHODS}

The experiment was carried out in the experimental poultry farm of the School of Veterinary and Animal Science a the Federal University of Goiás, located in Goiânia - GO, Brazil.

A total of 300 Bovans White chicks was housed in batteries with galvanized wire cages (50 $\times 50 \times 45 \mathrm{~cm}$ ) and holding capacity of 10 birds per cage $\left(25 \mathrm{~cm}^{2} /\right.$ bird $)$. Birds were received at one day of age and raised from the 1st to the 6th week of age, following the recommendations provided in the manual of the genetic line (Bovans White - Mercoaves Product Guide). The chicks were distributed in a completely randomized design in a $2 \times 2+1$ factorial arrangement consisting of two levels of crude fiber (CF) in the diet (3.0 and 3.5\%) and two feedstuffs with distinct fiber fraction compositions (wheat bran and sugarcane bagasse), plus a control treatment (2.5\% CF, composed of maize and soybean meal), totaling five treatments with six replicates of 10 birds each, in the starter phase.

All experimental diets were nutritionally equivalent, except for the fiber levels, following the nutritional recommendations stated in the manual of the line. The CF levels were determined from the maize- and soybean meal-based diet, which was defined as the control treatment, considering the maximum inclusion of 2.5 to $3.0 \% \mathrm{CF}$ in diets for monogastric animals (ROSTAGNO et al., 2017). The dietary CF inclusion levels of 3.0 and $3.5 \%$ were adopted for the other treatments, with sugarcane bagasse and wheat bran (Table 1). The composition of the fractions and sugars that make up the cell wall of fiber sources was determined (Table 2). For this step, representative samples of $1000 \mathrm{~g}$ of the feedstuffs were separated and analyzed at the Food Analysis Laboratory of AB Vista, a division of AB Agri Ltd. The formulation was made based on crude fiber, as it is described in the requirements tables, and can be considered usual in the formulation of diets for nonruminant animals.

The birds' behavior was determined initially by all-occurrence sampling to qualify the behavioral activities (Table 3) and develop the ethogram (PEREIRA et al., 2015). Natural behaviors of birds such as scratching and biting the litter, even in the absence of bedding material, were noticed in the sampling. In this case, the animal would bite and scratch on the cage floor, similarly to activities described on the litter. Therefore, they were considered in the ethogram, because, if constantly performed, they could represent discomfort of the bird. Subsequently, at the end of the 3rd and 6th weeks of the starter phase ( 21 and 42 days of age, respectively), the animals were recorded by video cameras on two consecutive days (20 and 21; and 41 and 42 days of age), in two periods of the day (08h00 and 13h00) (PEREIRA et al., 2015).Group representative of each replicate of the treatments were chosen, in a total of six 5-min recordings per period per treatment (ROYER et al., 2015). The birds' behaviors were evaluated by the focal and indirect animal observation method, whereby five randomly chosen birds were evaluated per replicate (HETLAND et al., 2005). The frequency of individual behaviors was obtained by simultaneously observing the animals. One-minute sessions of evaluation of activities were applied per bird, in a total of five evaluations per video of each replicate, per recording period, and then the average occurrence of each activity in the recorded videos was calculated (CASTRO et al., 2017). Subsequently, the five-minute recording was considered as representative of the activities in a day $(100 \%)$, in percentage terms, and the sum of the activities recorded in the evaluation session was considered the total number of activities developed in a day of life, per bird (PEREIRA et al., 2015).

The frequency of each activity predetermined in the ethogram (PEREIRA et al., 
Table 1 - Percentage and nutritional composition of the experimental diets in the starter phase (1-6 weeks of age).

\begin{tabular}{|c|c|c|c|c|c|}
\hline \multirow[t]{2}{*}{ Ingredient } & \multirow[t]{2}{*}{ Control } & \multicolumn{2}{|c|}{--------Sugarcane bagasse-------- } & \multicolumn{2}{|c|}{---'Wheat bran------- } \\
\hline & & $3.0 \%$ & $3.5 \%$ & $3.0 \%$ & $3.5 \%$ \\
\hline Maize & 65.30 & 65.78 & 60.00 & 63.63 & 51.20 \\
\hline Soybean meal $45 \%$ & 24.00 & 28.01 & 27.30 & 28.91 & 28.50 \\
\hline Limestone & 1.50 & 1.10 & 1.05 & 1.20 & 1.20 \\
\hline Dicalcium phosphate & 2.00 & 1.82 & 1.90 & 1.77 & 1.70 \\
\hline Starch & 2.50 & 1.00 & 1.10 & 0.00 & 1.40 \\
\hline Common salt & 0.80 & 0.41 & 0.45 & 0.41 & 0.45 \\
\hline DL-methionine & 0.50 & 0.14 & 0.30 & 0.12 & 0.20 \\
\hline Threonine & 1.30 & 0.00 & 0.40 & 0.00 & 0.00 \\
\hline Lysine & 0.60 & 0.04 & 0.50 & 0.00 & 0.05 \\
\hline Vitamin premix $^{1}$ & 0.50 & 0.50 & 0.50 & 0.50 & 0.50 \\
\hline Mineral premix ${ }^{2}$ & 0.10 & 0.10 & 0.10 & 0.10 & 0.10 \\
\hline Oil & 0.00 & 0.00 & 2.00 & 1.04 & 4.80 \\
\hline Sugarcane bagasse & 0.00 & 1.23 & 4.50 & 0.00 & 0.00 \\
\hline Wheat bran & 1.00 & 0.00 & 0.00 & 2.53 & 10.00 \\
\hline Total & 100 & 100 & 100 & 100 & 100 \\
\hline \multicolumn{6}{|c|}{ 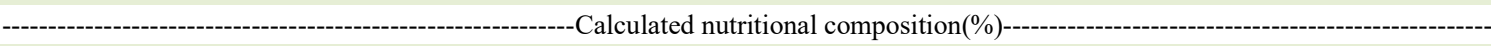 } \\
\hline Protein & 18.0 & 18.0 & 18.00 & 18.00 & 18.00 \\
\hline $\mathrm{ME}(\mathrm{kcal} / \mathrm{kg})$ & 2.900 & 2.900 & 2.900 & 2.900 & 2.900 \\
\hline Crude fiber & 2.5 & 3.0 & 3.5 & 3.0 & 3.5 \\
\hline $\operatorname{NDF}(\%)^{* *}$ & 14.8 & 17.7 & 16.7 & 19.1 & 25.3 \\
\hline $\operatorname{ADF}(\%)^{* *}$ & 11.6 & 12.1 & 13.1 & 12.0 & 11.6 \\
\hline Calcium & 1.34 & 0.95 & 0.94 & 0.94 & 0.95 \\
\hline Available P & 0.46 & 0.44 & 0.45 & 0.44 & 0.44 \\
\hline Sodium & 0.34 & 0.18 & 0.19 & 0.18 & 0.20 \\
\hline Digestible lysine & 1.22 & 0.87 & 1.21 & 0.88 & 0.92 \\
\hline Digestible methionine & 0.73 & 0.39 & 0.54 & 0.38 & 0.45 \\
\hline Digestible met + cys. & 0.95 & 0.64 & 0.78 & 0.64 & 0.71 \\
\hline Digestible threonine & 1.83 & 0.62 & 0.99 & 0.64 & 0.62 \\
\hline
\end{tabular}

${ }^{1}$ Vitamin supplement: vit. A - 1,600,000 IU; vit. D3 - 550,000 IU; vit. E - 2.500 mg; vit. K3 - 360 mg; vit. B1 - 480 mg; vit. B2 1,200 mg; vit. B6 - $500 \mathrm{mg}$; vit. B12 - 2,400 mg; niacin- 7,600 mg; pantothenic acid - 2,400 mg; folic acid - $200 \mathrm{mg}$; methionine 200,000 mg; choline - 60,000mg; L-lysine - 20,000 mg; salinomycin- 20,000 mg; biotin - $12 \mathrm{mg}$; silicon dioxide - $20 \mathrm{~g}$. ${ }^{2} \mathrm{Mineral}$ supplement: Fe - 10,000 mg; $\mathrm{Cu}-1,800 \mathrm{mg} ; \mathrm{Zn}-15,000 \mathrm{mg} ; \mathrm{Mn}-16,000 \mathrm{mg}$; I $180 \mathrm{mg}$; Se - 60 mg; ${ }^{*}$ Calculated; ${ }^{* *}$ Determined.

2015) was expressed by the following formula:

$\%$ of activity $=$ Number of times the animal performed the activity * $100 /$ Total number of activities performed.

This formula indicated the percentage of time spent by the animal on a given activity during the day (representative time of $5 \mathrm{~min}$ ) (ROYER et al., 2015). After the percentage of each activity was obtained, the behaviors were classified based on the values proposed for maintenance behaviors essential for the life (feeding and drinking), health and comfort (sleeping, lying down, scratching, preening, spreading wings, walking and others) of the animal (Table 5).The intervals proposed for the evaluation of representative behaviors to meet the essential needs of life and comfort were also defined (Table 5), as described by HURNIK (1995) and adapted by ALVES et al. (2007) and ROYER et al. (2015).

The mean values obtained in the two days of evaluation of each rearing period (third and sixth weeks) were evaluated per period. Data were analyzed by the Kruskal-Wallis non-parametric test (5\% probability), using R Software version 2.15. 1 (R CORE TEAM, 2013).

\section{RESULTS AND DISCUSSION}

There was no difference in behavior (Table 6) or in the classification by order of importance of the activities performed (Table 7, Figure 1A and 1B) by 
Table 2 - Composition in cell wall fractions of fiber sources (sugarcane bagasse: BC and wheat bran: WB) used in the formulations of experimental diets.

\begin{tabular}{|c|c|c|c|c|c|c|c|c|c|c|c|}
\hline \multirow[t]{2}{*}{ Feedstuff } & \multicolumn{2}{|c|}{--------Fraction-------- } & \multicolumn{8}{|c|}{ 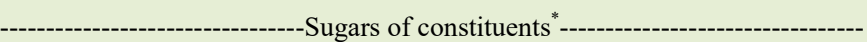 } & \multirow{2}{*}{$\begin{array}{l}\text { Total } \\
\mathrm{g} / 100 \mathrm{~g}\end{array}$} \\
\hline & NDF & $\mathrm{ADF}^{2}$ & Rha & Fuc & Ara & Xyl & Man & Gal & Glu & GalA & \\
\hline SB & 59.5 & 56.0 & 0.1 & 0.1 & 2.1 & 2.4 & 0.3 & 1.4 & 3.5 & 0.8 & 10.7 \\
\hline WB & 44.6 & 16.6 & 0.1 & 0.1 & 2.1 & 2.8 & 0.3 & 1.2 & 4.1 & 0.6 & 11.3 \\
\hline
\end{tabular}

Data are based on duplicate analysis and expressed in $\mathrm{g} / 100 \mathrm{~g}$;

${ }^{1}$ Fractions that make up the plant cell wall, represented by pectin, hemicellulose and portions of soluble cellulose.

${ }^{2}$ Fractions that make up the plant cell wall, represented by lignin and cellulose; ${ }^{*}$ Sugars that make up the fractions that constitute the cell wall and provide characteristics of solvation with water or formation of insoluble crystals, the main ones being Rha: rhamnose; Fuc: fucose, Ara, arabinose, Xyl: xylose, man: mannose, Gal: galactose, Glu: glucose, GalA, galacturonic acid.

laying hens fed diets containing sugarcane bagasse (fiber with a higher amount of insoluble fractions, ADF) and wheat bran (fiber with a higher amount of soluble fractions, NDF), at 21 and 42 days, according to the Kruskal Wallis test $(\mathrm{P}>0.05)$. However, in other studies evaluating the effects of increasing dietary fiber contents intake decreased due to the volume occupied in the digestive tract; the slower passage of the digesta; and the high-water absorption capacity of the soluble fractions that make up some feedstuffs (ASSUNÇÃO et al., 2018). This change in frequency of visits to the feeder may be due not only to the fiber content of the diet, but also to the bedding material, which expands the behavioral repertoire and substitutes water and feed consumption (MOURA et al., 2017) for dust bathing and foraging activities.

The replacement of activities in birds raised in cages when subjected to environmental changes, such as replacing feed consumption and the acts of biting neighboring birds and preening(GARCIA et al., 2015) with pecking and scratching the litter, is common and corresponds to exploration of the environment (PEREIRA et al., 2015). Nevertheless, even in cage farming, increases in the CF content and

Table 3 - Behaviors observed by all-occurrence sampling.

\begin{tabular}{|c|c|}
\hline Activity & Description \\
\hline Eating & Bird has its head in the feeder for feeding \\
\hline Drinking & Bird has its head in the trough-type drinker for drinking \\
\hline Frequency at drinker & Bird located next to the drinker without drinking water \\
\hline Frequency at feeder & Bird located next to the feeder without eating \\
\hline Preening & Bird examines its own feathers with its beak \\
\hline Stretching wings & Bird stretches a wing and a leg in the same body hemisphere \\
\hline Collecting feet & Movement characterized by the bird retracting one of the two legs towards the body while standing \\
\hline Head scratching & Bird scratches its head with one of its feet \\
\hline Scratching cage floor & $\begin{array}{l}\text { Another behavior considered typical of birds, characterized as bird exploring its territory with its feet and } \\
\text { beak (in the absence of bedding material, the bird explores the cage grid floor) }\end{array}$ \\
\hline Biting litter (cage floor) & Bird bites cage floor (in the absence of bedding material in the cage, the bird uses the cage grid) \\
\hline Biting another bird & Bird bites any part of another bird's body \\
\hline Biting cage & Bird bites the sides of the cage \\
\hline Sleeping & Bird in a resting state, with its chest and head resting on the bed; \\
\hline Watching while lying & Bird lies with the chest resting on the bed and the head raised, watching \\
\hline Walking from side to side & Bird walks from side to side \\
\hline Tonic immobility & $\begin{array}{c}\text { Behavior characterized as bird not displaying any movement, or seemingly not fitting into any of the } \\
\text { previous behaviors }\end{array}$ \\
\hline
\end{tabular}

Source: adapted from PEREIRA et al. (2015).

Ciência Rural, v.52, n.1, 2022. 
Table 4 - Classification of bird welfare conditions based on the classification of variables of behaviors essential to comfort and essential to life.

\begin{tabular}{|c|c|c|c|c|}
\hline \multirow[t]{2}{*}{ Essential to life } & \multirow[b]{2}{*}{$<30 \%$} & \multicolumn{2}{|c|}{-----Essential to comfort-- } & \multirow[b]{2}{*}{$>65 \%$} \\
\hline & & $30-50 \%$ & $50-65 \%$ & \\
\hline$>32 \%$ & Poor & Medium & Good & Poor \\
\hline $26-32 \%$ & Medium & Good & Good & Good \\
\hline $23-26 \%$ & Medium & Medium & Good & Medium \\
\hline $20-23 \%$ & Poor & Medium & Medium & Poor \\
\hline$<20 \%$ & Very Poor & Poor & Poor & Very Poor \\
\hline
\end{tabular}

Adapted from HURNIK (1995) and adapted by ALVES et al. (2007) and ROYER et al. (2015).

the use of feedstuffs with a higher amount of ADF and NDF in the diet can change behavioral patterns. VAN KRIMPEN et al. (2009) increased the ADF content (fractions with less metabolizable sugar constituents of the cell wall, such as some celluloses and lignin) in the diet of layers and noticed a lower incidence of feather pecking and cannibalism in laying birds reared in cages. This behavior is responsive to the birds' natural appetite for fiber sources, which improve the motility of the gizzard and intestines. BRAZ et al. (2011) increased the amount of fiber in chicken diets by increasing the inclusion of wheat bran (which increased the content of NDF, a soluble fraction) and observed that up to the limit at which it provided
$18.50 \%$ of NDF in the composition, the ingredient did not promote changes in the characteristics of the diet enough to compromise feed intake by the hens.

Considering inferences of the activities and intervals proposed by ALVES et al. (2007), medium and good welfare conditions were obtained with the use of wheat bran at the CF levels of 3.5 and 3.0\%, respectively, at 21 days of age. At 42 days, the use of sugarcane bagasse at the CF level of $3.5 \%$ and wheat bran at 3.0\% CF improved welfare conditions (Table 7).

The early age of birds for the research with nutrition and inclusion of fibers was chosen in response to the behavior of feather, back and cloaca pecking, which chicks may already present in the second week

Table 5 - Definition of the intervals proposed for the evaluation of representative behaviors to meet the essential needs for life and comfort.

\begin{tabular}{|c|c|}
\hline$\%$ of time & ------------------------Categorization----------------. \\
\hline \multicolumn{2}{|c|}{--1- } \\
\hline$>32$ & $\begin{array}{l}\text { Very poor (excess) - time spent on these activities exceeds the necessary, which may compromise free time for } \\
\text { other needs. }\end{array}$ \\
\hline 26-32 & $\begin{array}{l}\text { Poor - indicates that the bird spends too much time eating or drinking, which may be the result of frustration, } \\
\text { difficulty finding food or dissatisfaction. }\end{array}$ \\
\hline $23-26$ & $\begin{array}{l}\text { Good - indicates the expected values for this behavior, considering variations in the conditions of the rearing } \\
\text { environment. }\end{array}$ \\
\hline $20-23$ & Medium - range containing the minimum time limit required for the activities. \\
\hline$<20$ & Poor - time considered too little for meeting essential life needs, which may compromise the animal's productivity. \\
\hline \multicolumn{2}{|c|}{ 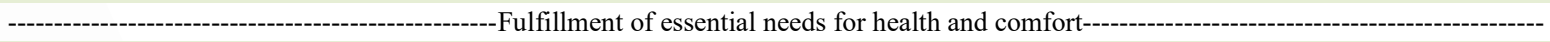 } \\
\hline$>65$ & Good - threshold of percentage of time considered good, allowing leftover time for behaviors essential to life; \\
\hline $50-65$ & Medium - range containing the minimum time limit required for the activities. \\
\hline $30-50$ & $\begin{array}{l}\text { Poor - time too limited to meet the needs of movement and execution of activities considered important or essential } \\
\text { to health and comfort. }\end{array}$ \\
\hline${ }^{*}<30$ & Very poor - time not sufficient to perform more than one activity, which is a reflection of poor welfare conditions. \\
\hline
\end{tabular}

Adapted from HURNIK (1995) ALVES et al. (2007) and ROYER et al. (2015).

Ciência Rural, v.52, n.1, 2022. 
Table 6 - Observed behaviors (\%) in hens in the starter phase, from 21 and 42 days of age, fed diets with different levels and sources of crude fiber.

\begin{tabular}{|c|c|c|c|c|c|c|c|c|c|c|}
\hline \multirow[b]{2}{*}{ Activity } & \multirow[b]{2}{*}{$\mathrm{C}^{*}$} & \multicolumn{2}{|c|}{----------SB ${ }^{*}$} & \multicolumn{2}{|c|}{--------WB ${ }^{*}------$} & \multirow[b]{2}{*}{$\mathrm{C}^{*}$} & \multicolumn{2}{|c|}{-------SB ${ }^{*}------$} & \multicolumn{2}{|c|}{-------WB ${ }^{*}-----$} \\
\hline & & $3.0 \%$ & $3.5 \%$ & $3.0 \%$ & $3.5 \%$ & & $3.0 \%$ & $3.5 \%$ & $3.0 \%$ & $3.5 \%$ \\
\hline & & \multicolumn{5}{|c|}{ 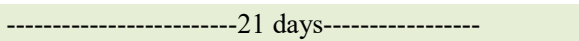 } & \multicolumn{4}{|c|}{--------------------42 days---------------- } \\
\hline Eating & 22.1 & 14.0 & 13.2 & 21.7 & 14.5 & 20.7 & 30.8 & 22.8 & 24.3 & 21.0 \\
\hline Drinking & 2.4 & 2.8 & 1.1 & 2.3 & 4.5 & 3.9 & 1.4 & 0.3 & 2.1 & 1.1 \\
\hline Frequency at feeder & 2.7 & 3.7 & 3.8 & 2.3 & 1.4 & 0.4 & 0.4 & 1.3 & 0.2 & 0.8 \\
\hline Frequency at drinker & 4.4 & 2.7 & 1.5 & 2.3 & 3.3 & 1.5 & 0.3 & 1.7 & 1.9 & 1.6 \\
\hline Preening & 14.9 & 12.8 & 11.7 & 10.8 & 13.1 & 12.0 & 5.3 & 15.3 & 7.7 & 8.8 \\
\hline Stretching wings & 1.4 & 0.3 & 1.4 & 0.71 & 1.3 & 0.7 & 1.5 & 1.1 & 0.7 & 0.6 \\
\hline Collecting feet & 3.9 & 1.0 & 2.8 & 1.1 & 3.7 & 1.1 & 2.8 & 2.1 & 2.2 & 2.1 \\
\hline Head scratching & 0.8 & 1.1 & 1.6 & 1.2 & 0.9 & 1.7 & 1.0 & 1.5 & 1.4 & 1.4 \\
\hline Ground scratching & 1.6 & 0.5 & 1.2 & 1.2 & 1.6 & 0.7 & 0.8 & 1.1 & 0.5 & 0.7 \\
\hline Biting others birds & 1.3 & 0.7 & 1.2 & 0.8 & 0.3 & 5.4 & 4.8 & 4.6 & 2.4 & 6.4 \\
\hline Biting bed & 2.9 & 2.1 & 4.1 & 2.4 & 3.5 & 0.6 & 0.6 & 1.3 & 1.6 & 1.8 \\
\hline Biting cage grid & 3.6 & 1.7 & 2.0 & 1.1 & 1.6 & 2.9 & 5.6 & 2.2 & 0.4 & 0.9 \\
\hline Sleeping & 6.0 & 6.8 & 6.8 & 8.7 & 6.3 & 6.4 & 7.5 & 4.2 & 8.1 & 5.7 \\
\hline Watching while lying & 4.1 & 10.7 & 8.9 & 12.7 & 7.9 & 17.0 & 8.1 & 19.8 & 16.4 & 14.7 \\
\hline Tonic immobility & 10.4 & 20.8 & 12.7 & 9.5 & 12.7 & 12.3 & 19.2 & 10.7 & 10.7 & 14.1 \\
\hline Walking from side to side & 17.3 & 19.3 & 25.4 & 20.7 & 22.8 & 18.7 & 18.3 & 13.1 & 19.2 & 18.7 \\
\hline
\end{tabular}

Means followed by different letters differ by the Kruskal Wallis test at the $5 \%$ significance level, rejecting the H0 hypothesis. ${ }^{*}$ SB: sugarcane bagasse; WB: wheat bran; C: control.

of life (VAN HIERDEN et al., 2002; FREITAS et al., 2014). Therefore, beak trimming is conventionally performed with industrial machine and burning of the tip of the beak of birds, to avoid cannibalism inside the cages. In the first weeks of life, chicks sleep and play more, reducing food consumption, constantly stimulated to visit the feeder (MATEOS et al., 2012; FREITAS et al., 2014). In this period, some authors also describe the development of digestive organs that may interfere in the utilization of nutrients and consequent reproductive development. The hypothesis questioned in this study was the possibility of including fiber in the

Table 7 - Welfare conditions of hens at 21 and 42 days of age based on the inferences of activities and their importance for animal development.

\begin{tabular}{|c|c|c|c|c|c|c|}
\hline & Essential to life $^{*}$ & Comfort and health ${ }^{* *}$ & Condition & Essential to life ${ }^{*}$ & Comfort and health ${ }^{* *}$ & Condition \\
\hline \multicolumn{7}{|c|}{ 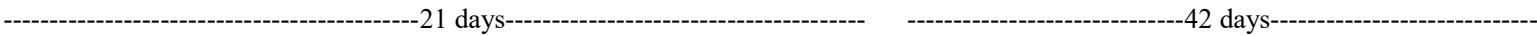 } \\
\hline $3.0 \mathrm{SB}$ & 22.0 & 78.0 & Poor & 32.8 & 75.6 & Poor \\
\hline $3.5 \mathrm{SB}$ & 19.7 & 80.3 & Very poor & 26.1 & 76.9 & Good \\
\hline $3.0 \mathrm{WB}$ & 28.8 & 71.3 & Good & 28.5 & 68.3 & Good \\
\hline $3.5 \mathrm{WB}$ & 23.8 & 76.2 & Medium & 24.6 & 76.3 & Poor \\
\hline Control & 31.4 & 68.6 & Good & 26.4 & 79.4 & Good \\
\hline
\end{tabular}

"Activities essential to life: eating, drinking and sleeping; essential to comfort and health" ${ }^{* *}$ head scratching, stretching wings and preening (cleaning and tidying the feathers), walking from side to side and ground scratching (exploring the environment), lying (rest) and biting cage grid and bed (escape from idleness). Means do not differ by the Kruskal Wallis test at the 5\% significance level.

$\mathrm{SB}=$ sugarcane bagasse.

$\mathrm{WB}=$ wheat bran. 


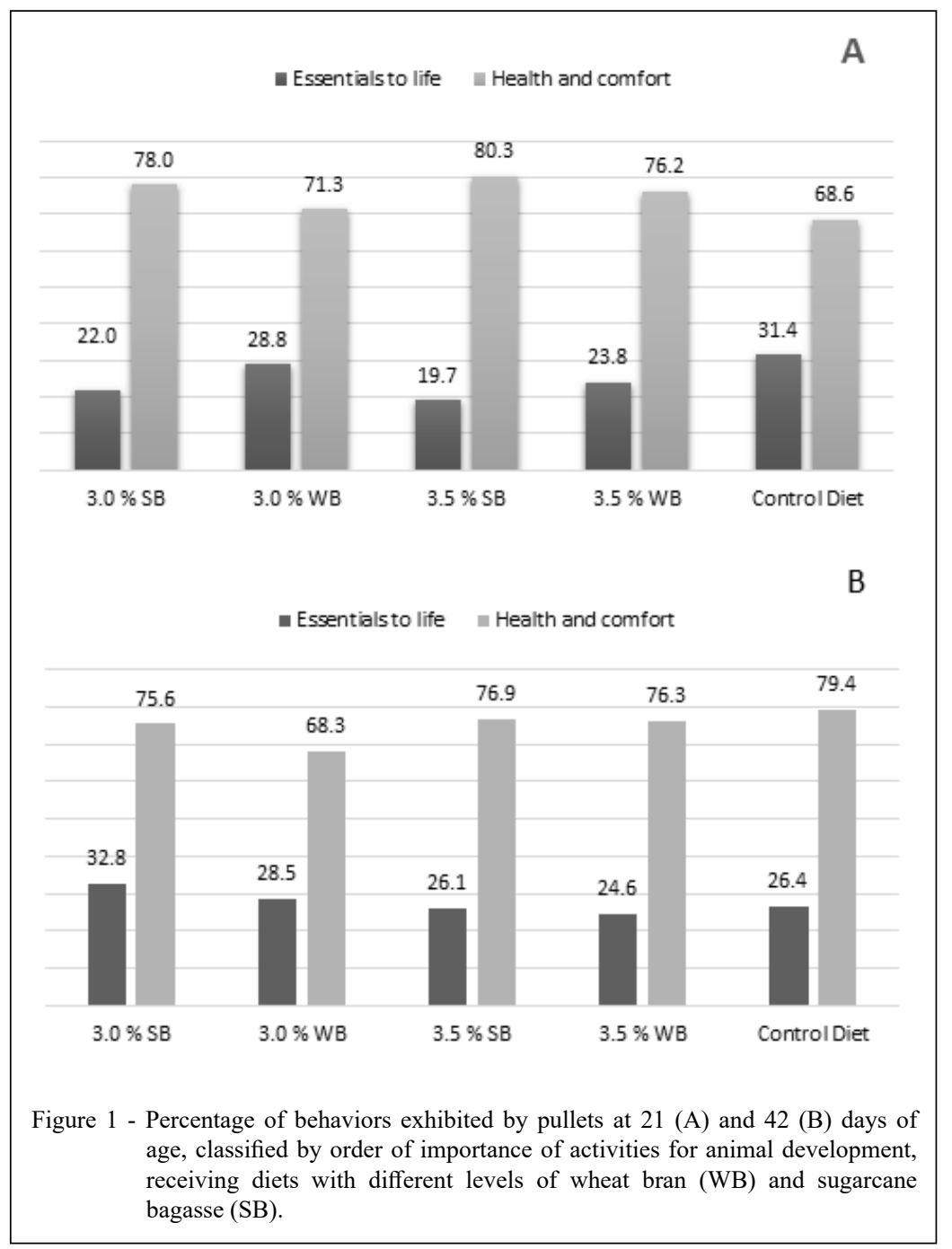

diet with two sources and levels: sugarcane bagasse and wheat bran, which may alter the consumption behavior. Responsive to the higher speed of passage through the digestive tract, causing the birds to return to the feeder more often, reducing the time of sleep and play, as well as the reduction of cannibalism behavior, since they are busy eating and do not peck the neighboring birds. This consumption of food, consequently, stimulate the functioning of the digestive organs and the presence of fiber, could stimulate the activity of the gizzard, causing its muscle development and increase in size. In a research carried out by GONZÁLEZ-ALVARADO et al. (2007) it was noticed that with the increase of the oat hulls and soy hulls, the size of the gizzard and digestive organs, including pancreas, was also increased, indicating its greater activity in the production of digestive secretion. This can interfere in the digestibility of the nutrients in the diet, with its greater utilization and consequent greater development of the bird, especially of the reproductive tract. VAN KRIMPEN et al. (2009) described a natural appetite for the consumption of fiber sources by birds to improve the motility of and intestine, which in turn, may lead to birds consume litter, pecking and plucking the feathers of the neighboring birds. As the pecking of feathers and cannibalism occurs already in the first weeks and is indicative of low conditions of well-being, and as the stage of offspring, especially the first four weeks of age are important for the quality of the chicken, the study was considered already in the stage of offspring.

Diet formulation with increasing levels of fiber has been studied in laying hens diets. The composition of the cell wall of vegetables varies

Ciência Rural, v.52, n.1, 2022. 
among foods, some sugars that make up the fractions of the cell wall may have different behaviors with regard to solubility and may present greater or better metabolization (de VRIES, 2013). Important reviews were published by AKINOLA \& ONUNKWO (2009); MATEOS et al. (2012) and recently by SINGH and KIM (2021). Ingredients with a higher amount of acid detergent fiber (ADF) fractions, for example, can impair diet metabolization and increase the rate of passage through the digestive tract or cause damages in intestinal villi. This reduces the absorption of nutrients and can increase the frequency to the eating of birds. However, this content in ADF, can supply the natural need of the bird by fibrous materials, because it alters the motility of the intestine, reducing depraved behaviors, such as pecking of the feathers and of other birds.

The rations for non-ruminant animals are commonly not formulated in the composition of neutral detergent fiber (NDF) and ADF, but in CF (FREITAS et al., 2014). Therefore, in this experiment, the recommended levels of fiber were used, evaluating diets with the same level of $\mathrm{CF}$, but with feedstuffs that have distinct fractions of sugars that are constituents of the cell wall. According to MATEOS et al. (2013), it is important to understand the way in which the constituents behave metabolically, and how they interfere in animal behavior. Since low nutrient absorption, possible reduction or increase in gastric motility and the supply of natural bird needs can alter natural behaviors, increase or reduce stereotypes. With these results, we could also increase the number of ingredients used in the feeding of non- ruminant animals, with residues such as sugarcane bagasse or other co-products, reducing the use of corn and soybeans and consequent competition with human consumption and feed costs of the activity.

\section{CONCLUSION}

The use of diets with increasing levels of crude fiber did not change the behavior of laying hens' chicks at 21 and pullets at 42 days of age.

\section{ACKNOWLEDGEMENTS}

To Fundação de Amparo à Pesquisa do Estado de Goiás (FAPEG), Mercoaves Comércio de Aves LTDA, Nutrial Alimentos, Tectron and Escola de Veterinária e Zootecnia da Universidade Federal de Goiás (UFG).

The authors thank $\mathrm{CNPq}$ - National Council for Scientific and Technological Development for the undergraduate scientific fellowship granted to the first author and senior researcher fellowship granted to the seventh author.

\section{BIOETHICS \\ AND \\ BIOSSECURITY \\ COMMITTEE APPROVAL}

The research project was fully analyzed and approved by the Ethics Committee on Animal Use (CEUA/UFG; approval no. 078/2014).

\section{DECLARATION OF CONFLICT OF INTEREST}

The authors declare no conflict of interest. The founding sponsors had no role in the design of the study; in the collection, analyses, or interpretation of data; in the writing of the manuscript, and in the decision to publish the results.

\section{AUTHORS' CONTRIBUTIONS}

The authors contributed equally to the manuscript.

\section{REFERENCES}

AKINOLA, L. A. F.; ONUNKWO, D. N. A review on the role of fiber in poultry nutrition. Environment \& Ecology, v.27, n.4 A, p.1689-1691, 2009. Available from: <www.cabdirect.org/ cabdirect/abstract/20103048990>. Accessed: Jan. 22, 2021.

ALVES, S. P. et al. Laying hens welfare evaluation: effects of rearing system and bioclimatic environment on performance and egg quality. Revista Brasileira de Zootecnia, v.36, n.5, p.13881394, 2007. Available from: <https://doi.org/10.1590/S151635982007000600023>. Accessed: Jul. 10, 2019. doi: 10.1590/ S1516-35982007000600023

ASSUNÇÃO, A. S. A. et al. Performance and quality of laying hens fed barley bagasse levels in the feed. Boletim Indústria Animal, v.75, p.1-10, 2018. Available from: <https://doi.org/10.17523/bia.2018. v75.1410>. Accessed: Jul. 10, 2019. doi: 10.17523/bia.2018.v75.1410.

BATISTIOLI, J. S. et al. Study of the behavjor of commercial Embrapa 051 laying hens raised on free system without beak trimming in storage density. Revista Unimar Ciências, v.25, n.1-2, p.45-52, 2016. Available from: $<$ http://ojs.unimar.br/index.php/ciencias/issue/ view/12>. Accessed: Feb. 28, 2020. doi: 10.1038/pr.2011.949.

BOVANS WhITE. Product Guide/ Cage Production System. Mercoaves, Bom Principio - RS. 47 p. Online. Available from: $<$ https://www.bovans.com/pt-br/bovans-white-and-bovans-brownlayers-pt-br/bovans-white-pt-br/>. Accessed: Feb. 28, 2020.

BRAZ, N. M, et al. Fiber in the growth ration and its effects on the performance of laying hens in the growth and laying phases. Revista Brasileira de Zootecnia, v.40, n12, p.2744-2753, 2011. Available from: $\quad<$ https://doi.org/10.1590/S1516-35982011001200019>. Accessed: Apr. 01, 2020. doi: 10.1590/S1516-35982011001200019.

CASTRO, J. O. et al. Behavior of Japanese cordons subjected to different temperatures. Revista Energia na Agricultura, v.32, n.2, p.141-147, 2017.Available from: <https://doi.org/10.17224/ EnergAgric.2017v32n2p141-14>. Accessed: Apr. 01, 2020. doi: 10.17224/EnergAgric.2017v32n2p141-147.

FREITAS, E. R. et al. Fiber level for laying hens during the growing phase. Ciência e Agrotecnologia, v.38, n.2, p.188-198, 
2014. Available from: <https://www.scielo.br/pdf/cagro/v38n2/ a10v38n2.pdf>. Accessed: Jan. 22, 2021. doi: 10.1590/S141370542014000200010 .

GARCIA, E. R. de M. et al. Behavior of laying hens reared at different housing population densities. Arquivo de Ciência Veterinária e Zootecnia, v.18, n.2, p.87-93, 2015. Available from: $<$ https://doi.org/10.25110/arqvet.v18i2.2015.5378>. Accessed: Mar. 16, 2019. doi: 10.25110/arqvet.v18i2.2015.5378.

GONZÁLEZ-ALVARADO, J. M. et al. Effects of type of cereal heat processing of the cereal, and inclusion of fiber in the diet on productive performance and digestive traits of broilers. Poultry Science, v.86, n.8, p.1705-1715, 2007. Available from: <https:// www.sciencedirect.com/science/article/pii/S0032579119403878>. Accessed: Jan. 22, 2021. doi: 10.1093/ps/86.8.1705.

GUZMÁN, P. et al. Inclusion of fiber in diets for brown-egg laying pullets: Effects on growth performance and digestive tract traits from hatching to 17 weeks of age. Poultry Science, v.94, p.27222733, 2015. Available from: <https://doi.org/10.3382/ps/pev288>. Accessed: Sep. 28, 2019. doi: 10.3382/ps/pev288.

HETLAND, H. et al. Role of insoluble fiber on gizzard activity in layers. Journal of Applied Poultry Research, v.14, p.38-46 2005. Available from: <https://doi.org/10.1093/japr/14.1.38>. Accessed: Sep. 27, 2019. doi: 10.1093/japr/14.1.38.

VAN HIERDEN, Y. M. et al. The development of feather pecking behaviour and targeting of pecking in chicks from a high and low feather pecking line of laying hens. Applied Animal Behaviour Science, v.77, n.3, p.183-196, 2002. Available from: <https://doi.org/10.1016/S01681591(02)00046-1>. Accessed: Mar. 24, 2021. doi: 10.1016 S0168-1591(02)00046-1.

HURNIK, J. F. Poultry Welfare. In. HUNTON, P. Poultry Production. Amsterdam, Lausanne, New York, Oxford, Shannon and Tokyo: Elsevier, 1995. Cap. 3, p.561-578.

MANCABELLI, L. et al. Insights into the biodiversity of the gut microbiota of broiler chickens. Environmental Microbiology, v.18, n.12, p.4727-38, 2016. Available from: <https://doi. org/10.1111/1462-2920.13363>. Accessed: Feb. 27, 2020. doi: $10.1111 / 1462-2920.13363$.

MATEOS, G. G. et al. Poultry response to high levels of dietary fiber sources varying in physical and chemical characteristics. Journal of Applied Poultry Research, v.21, n.1, p.156-174, 2012. Available from: $<$ https://doi.org/10.3382/japr.2011-00477> Accessed: Jan. 22, 2021. doi: 10.3382/japr.2011-00477.
MATEOS, G. G. et al. Relevance of dietary fiber in poultry feeding. $20^{\mathrm{TH}}$ European Symposium of Poultry Nutrition, 2013. Potsdam, Germany. Proceedings..., Potsdam: WPSA, 2013. Available from: <https://www.researchgate.net/ publication/298422782_Relevance_of_dietary_fiber_in_poultry feeding $>$. Accessed: Jan. 22, 2021.

MOURA, G. R. S. et al. Semi-heavy laying chickens reared on different types of bedding. Revista Brasileira de Saúde e Produção Animal, v.18, n.2, p.378-387, 2017. Available from: <https://doi.org/10.1590/s1519-99402017000200016>. Accessed: Mar. 16, 2019. doi: 10.1590/s1519-99402017000200016.

PEREIRA, D. F. et al. Behavioral differences of laying hens in different thermal environments. Revista Energia na Agricultura, v.30, n.1, p.32-39, 2015. Available from: $<$ https://doi.org/10.17224/ EnergAgric.2015v30n1p33-40>. Accessed: Apr. 01, 2020. doi: 10.17224/EnergAgric.2015v30n1p33-40.

R CORE TEAM. R: A language and environment for statistical computing. R Foundation for Statistical Computing, Vienna, Austria. 2013. Online. Available from: <https://www.r-project. org/>. Accessed: Jan. 18, 2018.

ROSTAGNO, H. S. et al. Brazilian tables for poultry and pigs: food composition and nutritional requirements. Viçosa: Editora da UFV, 2017.4 v. 488p.

ROYER, A. F. B. et al. Welfare of Broilers Ingesting a PreSlaughter Hydric Diet of Lemon Grass. Brazilian Journal of Poultry Science, v.17, n.3, p.301-306, 2015. Available from: $<$ https://doi.org/10.1590/1516-635x1703301-306>. Accessed: Mar. 16, 2019. doi: 10.1590/1516-635x1703301-306.

SINGH, A. K.; KIM, W. K. Effects of Dietary Fiber on Nutrients Utilization and Gut Health of Poultry: A Review of Challenges and Opportunities. Animals, v.11, n.181, 2021. Available from: $<$ https://doi.org/10.3390/ani11010181>. Accessed: Jan. 22, 2021. doi: 10.3390/ani11010181.

VAN KRIMPEN, M. M. et al. Effects of nutrient dilution and nonstarch polysaccharide concentration in rearing and laying diets on eating behavior and feather damage of rearing and laying hens. Poultry Science, v.88, p.759-773, 2009. Available from: <https:// doi.org/10.3382/ps.2008-00194>. Accessed: Mar. 16, 2019. doi: 10.3382/ps.2008-00194

VRIES, S de. Fiber in poultry nutrition: bonus or burden? $20^{\mathrm{TH}}$ European Symposium of Poultry Nutrition, 2013. Potsdam, Germany. Proceedings..., Potsdam: WPSA, 2013. Available from: $<$ https://www. researchgate.net/publication/281437747_FIBER_IN_POULTRY NUTRITION BONUS OR BURDEN>. Accessed: Jan. 22, 2021. 